Supporting information

\title{
One-pot tandem dehydration-hydrogenation of xylose with formic acid over Co catalysts
}

Authors:

Ling Xu ${ }^{\text {a }}$, Renfeng $\mathrm{Nie}^{\mathrm{b}^{*}}$, Haifeng Xu ${ }^{\mathrm{a}}$, Xujie Chen ${ }^{\mathrm{a}}$, Yanchen $\mathrm{Li}^{\mathrm{a}}$, Xiuyang $\mathrm{Lu}^{\mathrm{a}^{*}}$

Address:

a Key Laboratory of Biomass Chemical Engineering of Ministry of Education, College of Chemical and Biological Engineering, Zhejiang University, Hangzhou 310027, PR China

${ }^{\mathrm{b}}$ Hubei Collaborative Innovation Center for Advanced Organic Chemical Materials, \& Ministry-of-Education Key Laboratory for the Synthesis and Application of Organic Functional Molecules, School of Chemistry and Chemical Engineering, Hubei University, Wuhan 430062, P.R. China

* Corresponding authors

Renfeng Nie, Tel/Fax: 86-27-88662747

Email: refinenie@163.com

Xiuyang $\mathrm{Lu}$

Email: luxiuyang@,zju.edu.cn

\section{Experimental Procedures}

\section{Maierials}

1,10-phenanthroline (99\%) was purchased from Innochem, China. FAL (99\%), FOL (98 \%), D-xylose (98 \%), D-glucose (99.5\%), D-fructose (99\%), D-xylulose $(95 \%)$, sucrose (AR), lactose $(98 \%), \mathrm{Co}(\mathrm{OAc})_{2} \cdot 4 \mathrm{H}_{2} \mathrm{O}(99.9 \%), \mathrm{Ni}(\mathrm{OAc})_{2} \cdot 4 \mathrm{H}_{2} \mathrm{O}$ $(99.9 \%), \mathrm{Cu}(\mathrm{OAc})_{2} \cdot \mathrm{H}_{2} \mathrm{O}(99 \%), \mathrm{Fe}(\mathrm{OAc})_{2}(99 \%), \mathrm{Pt} / \mathrm{C}(5 \mathrm{wt} \%), \mathrm{Pd} / \mathrm{C}(5 \mathrm{wt} \%)$, 
$\mathrm{Ru} / \mathrm{C}(5 \mathrm{wt} \%)$ were purchased from Aladdin Chemicals. Nano $\mathrm{MgO}(99.9 \%, 50 \mathrm{~nm})$, FA (98 \%) were purchased from Macklin, China. $\mathrm{HNO}_{3}(65-68 \%)$, 1,4-dioxane ( $\geq 99.5 \%$ ), methanol ( $\geq 99.5 \%$ ) were purchased from Sinopharm Chemical Reagent Co. Ltd, China. All chemicals were used without any further treatment.

\section{Catalyst preparation}

$\mathrm{Co}-\mathrm{N}-\mathrm{C}$ catalysts were prepared via pyrolysis of the mixture of $\mathrm{Co}(\mathrm{phen})_{\mathrm{x}}(\mathrm{OAc})_{2}$ and nano- $\mathrm{MgO}$ in nitrogen atmosphere. Typically, $\mathrm{Co}(\mathrm{OAc})_{2} \cdot 4 \mathrm{H}_{2} \mathrm{O}(147 \mathrm{mg})$ and 1,10-phenanthroline monohydrate $(330 \mathrm{mg})$ were added into $50 \mathrm{~mL}$ ethanol to form a transparent solution. After that, nano- $\mathrm{MgO}(3.16 \mathrm{~g})$ was added and the suspension was sonicated for $10 \mathrm{~min}$. The mixture was stirred at $60{ }^{\circ} \mathrm{C}$ overnight. After ethanol was removed by rotary evaporation, the solid was dried, and heated to a $700{ }^{\circ} \mathrm{C}$ in $\mathrm{N}_{2}$ atmosphere at a heating rate of $2{ }^{\circ} \mathrm{C} / \mathrm{min}$ and kept for $2 \mathrm{~h}$. The calcinated solid was treated by $\mathrm{HNO}_{3}$ solution $(100 \mathrm{~mL}, 1 \mathrm{~mol} / \mathrm{L})$ in order to completely remove $\mathrm{MgO}$ and soluble cobalt species. The resulting sample was thoroughly washed with DI water until free of $\mathrm{Mg}^{2+}$ and $\mathrm{Co}^{2+}$, dried and named as Co-N-C. Replacing cobalt acetate with nickel acetate, ferric acetate or copper acetate gave rise to $\mathrm{Ni}-\mathrm{N}-\mathrm{C}, \mathrm{Fe}-\mathrm{N}-\mathrm{C}$ or $\mathrm{Cu}-\mathrm{N}-\mathrm{C}$, respectively.

\section{Characterizations}

Powder X-ray diffraction (XRD) was carried out with Ni-filtered $\mathrm{Cu} \mathrm{Ka}$ $(\lambda=0.154 \mathrm{~nm})$ operating at $40 \mathrm{kV}$ and $30 \mathrm{~mA}$ on a Bruker D8 diffractometer. Raman spectra were collected at room temperature from 100 to $3000 \mathrm{~cm}^{-1}$ with $532 \mathrm{~nm}$ argon ion laser (LabRAM HR Evolution). Transmission electron microscope (TEM) images were obtained using an accelerating voltage of $200 \mathrm{kV}$ on a JEOL 2100F Transmission Electron Microscope. X-ray photoelectron spectra (XPS) were recorded on a Thermo Scientific ESCALab 250Xi employing a $200 \mathrm{~W}$ monochromatic Al Ka radiation $(h v=1486.6 \mathrm{eV}) . \mathrm{C} 1 \mathrm{~s}$ at $284.6 \mathrm{eV}$ was used for calibrating the XPS spectra.

\section{One-pot synthesis of FOL from xylose}


The reactions were carried out in an autoclave $(8 \mathrm{~mL})$ purchased from Zhengxin, China. In a typical run, $0.20 \mathrm{mmol}$ xylose, $30 \mathrm{mg}$ catalyst, a certain amount of FA and $3.5 \mathrm{~mL}$ mixture of 1,4-dioxane and water were added into the autoclave. The sealed autoclave was purged, pressurized with $\mathrm{N}_{2}$ to $0.5 \mathrm{MPa}$ and heated to $160{ }^{\circ} \mathrm{C}$ under magnetic stirring $(500 \mathrm{rpm})$. After the completion of reaction, the autoclave was quickly soaked within cold water. The liquid was diluted with methanol. The xylose was analyzed by HPLC/RID (Agilent 1100). The FOL and FAL were analyzed by GC/FID (Agilent 7890A) and were confirmed by GC-MS (Agilent 5977A MSD). A quantitative analysis was performed using calibration curves for every compound in the mixture. All data were calculated by the average of three replicate experiments. After the reaction, the catalyst was successively washed by methanol for 3 times and then dried at $80{ }^{\circ} \mathrm{C}$ for $12 \mathrm{~h}$. The recovered catalyst was submitted to the next batch of reaction.

\section{Analysis method}

The FAL and FOL were quantitatively analyzed via gas chromatography (GC, Agilent 7890A) with a capillary column (HP-5, $30 \mathrm{~m} \times 0.32 \mathrm{~mm} \times 0.25 \mu \mathrm{m})$ using a flame ionization detector (FID). The carrier gas was nitrogen, and the temperature of the injector and detector were $250^{\circ} \mathrm{C}$ and $320^{\circ} \mathrm{C}$, respectively. A quantitative analysis was performed using calibration curves for every compound in the mixture. The FAL and FOL were qualitatively identified via gas chromatography-mass spectrometry (GC-MS, Agilent 5977A MSD) system, and the retention times of the unknown products with known standards were matched on the gas chromatograph. The xylose was quantitatively analyzed via high performance liquid chromatography (HPLC, Agilent 1100) with a colum (Aminex HPX-87H, $300 \mathrm{~mm} \times 7.8 \mathrm{~mm}$ I.D., Bio-Rad Laboratories, Inc.). The flow rate of mobile phase (5 mmol/ $\left.\mathrm{L} \mathrm{H}_{2} \mathrm{SO}_{4}\right)$ was 0.4 $\mathrm{mL} / \mathrm{min}$. The temperature of the column and the RID were $60{ }^{\circ} \mathrm{C}$ and $35{ }^{\circ} \mathrm{C}$, respectively. Reactant mole conversions were obtained as the number of moles of reactant consumed divided by the initial number of moles of reactant added to the reactor. Selectivity was calculated by the number of moles of product recovered 
divided by the number of moles of reactant reacted. All data were calculated by the average of three replicate experiments.
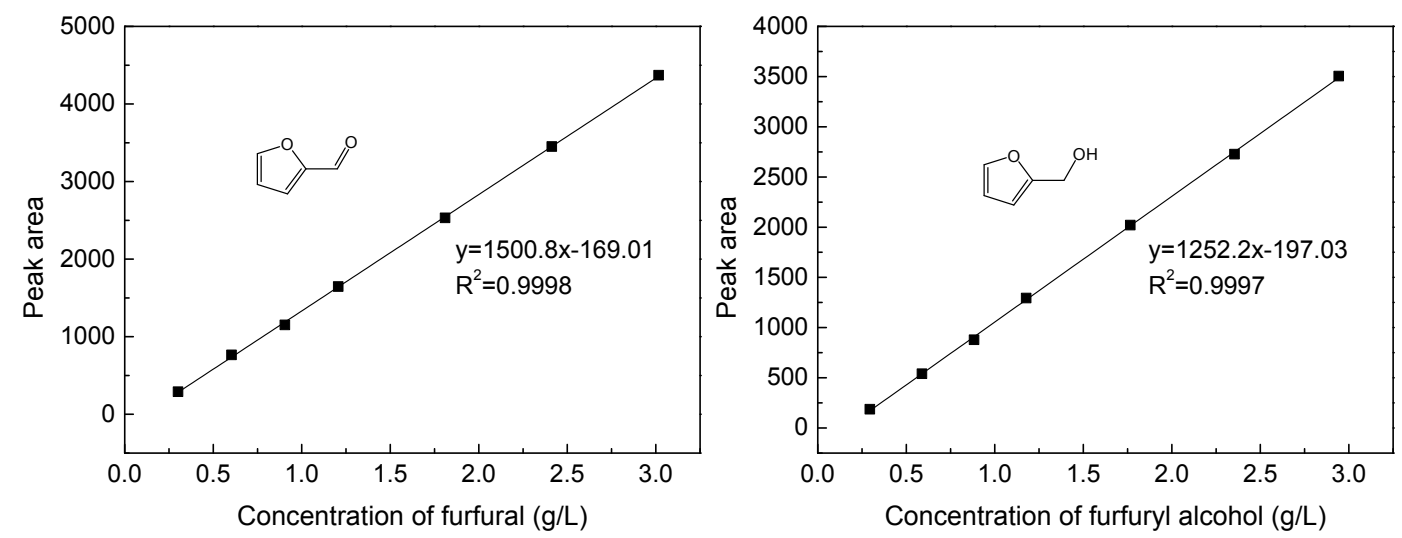

Fig. S1 Standard curves of furfural (left) and fufuryl alcohol (right) for GC analysis.
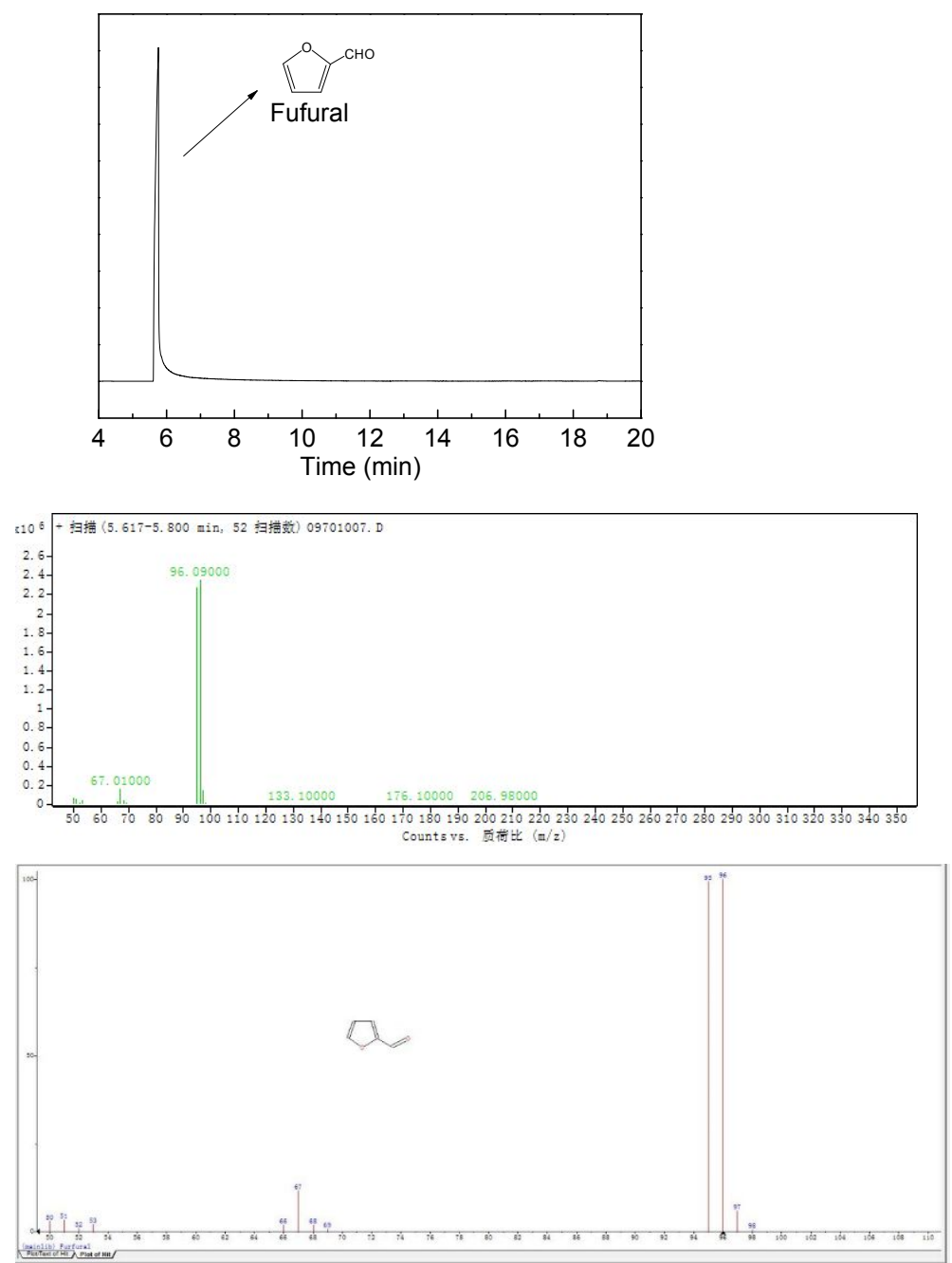

Fig. S2 GC-MS profiles of FAL. Reaction conditions: xylose $(0.2 \mathrm{mmol})$, $\mathrm{FA} /$ xylose $=20$ (mole ratio), solvent (water+1,4-dioxane, $3.5 \mathrm{~mL})$, water content $(22 \%$, 
v/v), $0.5 \mathrm{MPa} \mathrm{N}_{2}, 160^{\circ} \mathrm{C}, 3 \mathrm{~h}, 500 \mathrm{rpm}$.
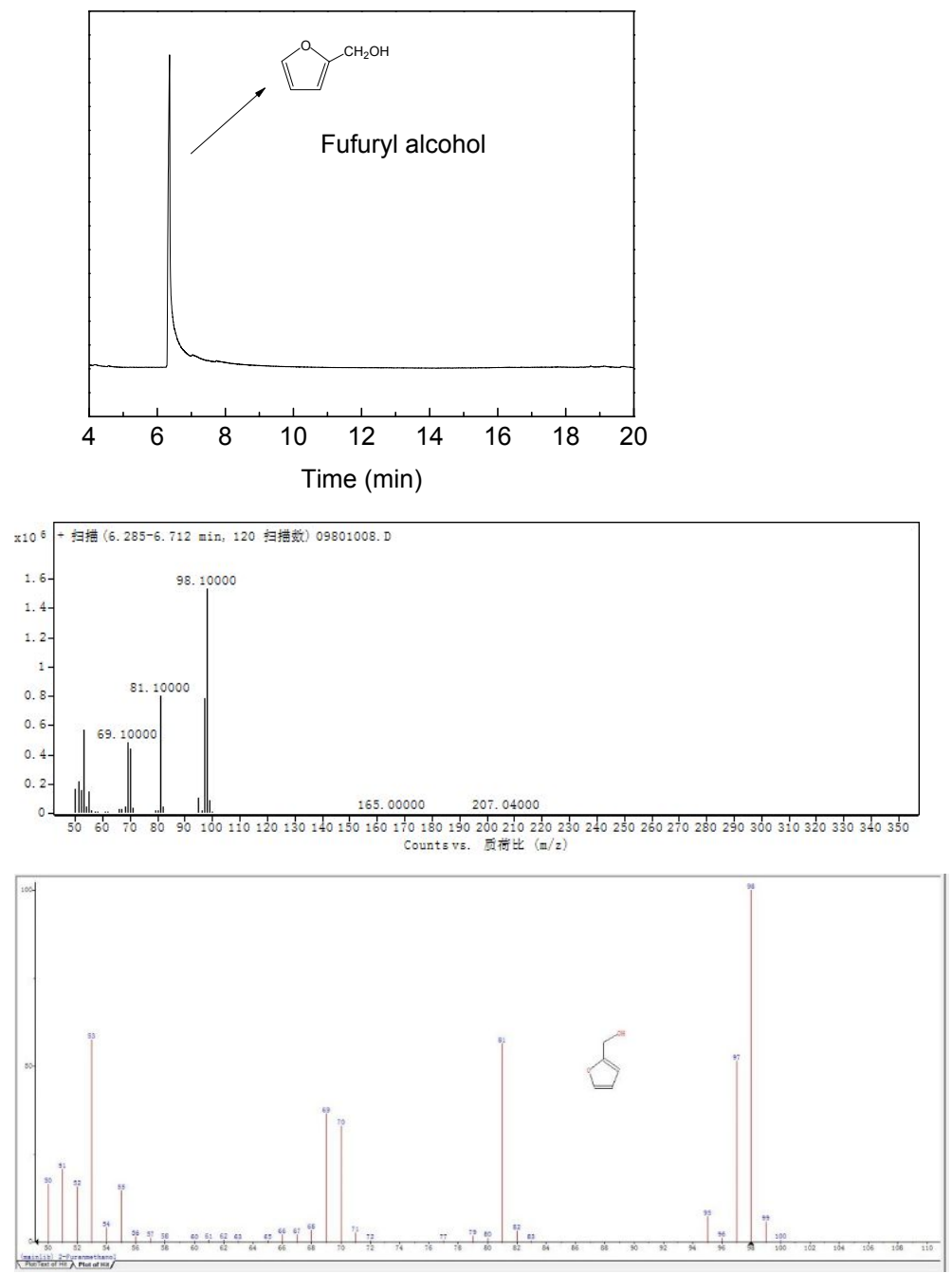

Fig. S3 GC-MS profiles of FOL. Reaction conditions: xylose (0.2 mmol), Co-N-C (30 $\mathrm{mg}$ ), FA/xylose $=20$ (mole ratio), solvent (water+1,4-dioxane, $3.5 \mathrm{~mL}$ ), water content $\left(22 \%\right.$, v/v), $0.5 \mathrm{MPa} \mathrm{N}_{2}, 160{ }^{\circ} \mathrm{C}, 3 \mathrm{~h}, 500 \mathrm{rpm}$. 


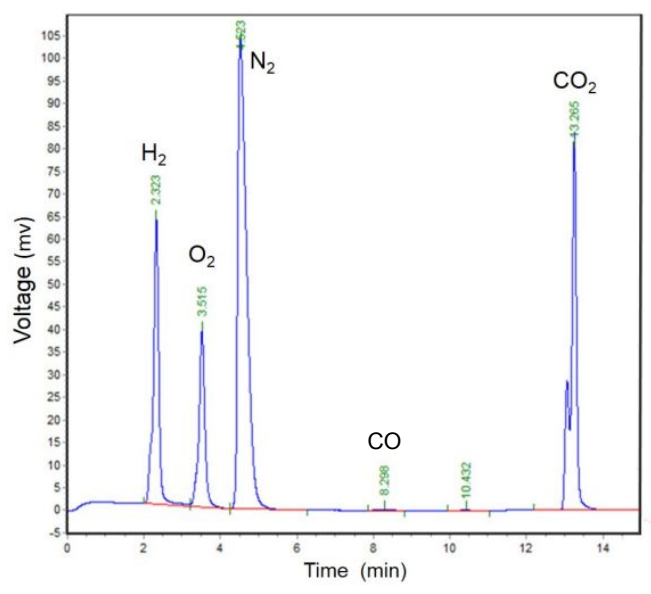

Fig. S4 GC spectrum of FA dehydrogenation over Co-N-C. (The observed $\mathrm{O}_{2}$ and $\mathrm{N}_{2}$ were extraneous gases due to the gas analysis)

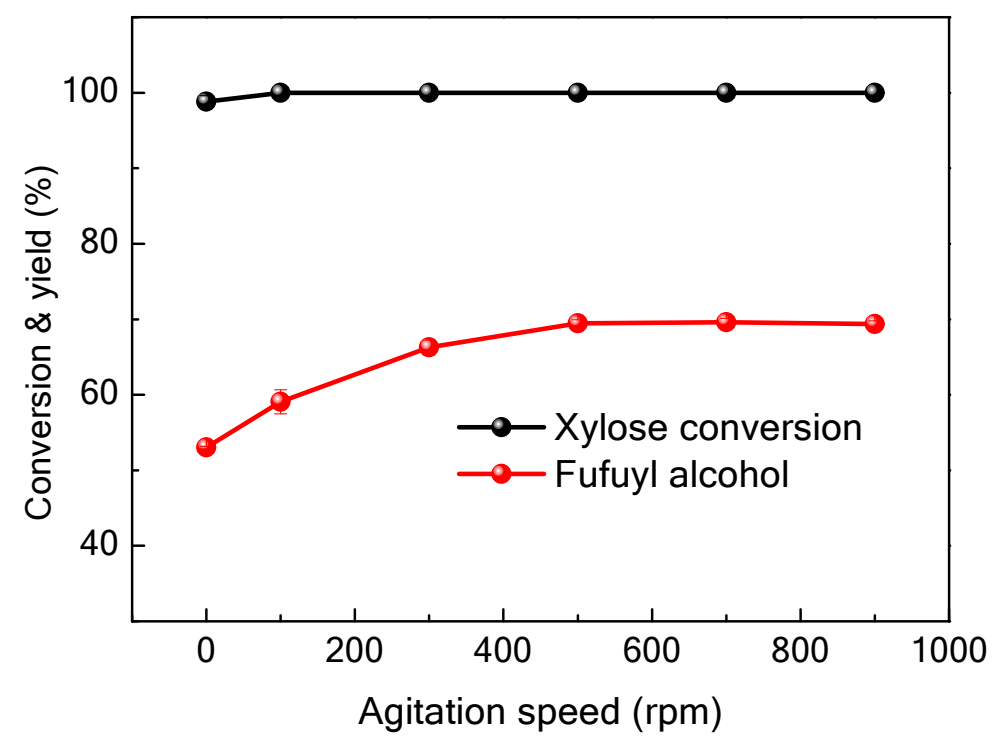

Fig. S5 Effect of agitation speed on one-pot conversion of xylose over Co-N-C. Reaction conditions: xylose $(0.2 \mathrm{mmol}), \mathrm{Co}-\mathrm{N}-\mathrm{C}(30 \mathrm{mg}), \mathrm{FA} / \mathrm{xylose}=20$ (mole ratio), solvent (water+1,4-dioxane, $3.5 \mathrm{~mL}$ ), water content $\left(22 \%\right.$, v/v), $0.5 \mathrm{MPa} \mathrm{N} \mathrm{N}_{2}, 160{ }^{\circ} \mathrm{C}$, $3 \mathrm{~h}$. 


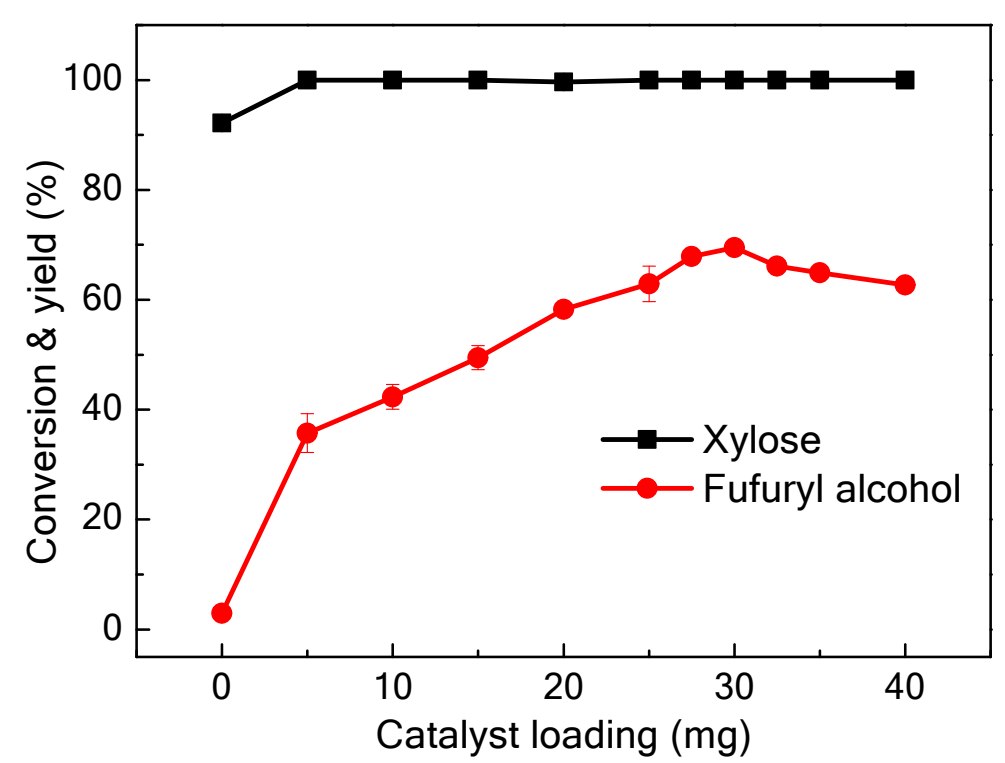

Fig. S6 Effect of catalyst loading on one-pot conversion of xylose over Co-N-C. Reaction conditions: xylose $(0.2 \mathrm{mmol}), \mathrm{FA} / \mathrm{xylose}=20$ (mole ratio), solvent (water+1,4-dioxane, $3.5 \mathrm{~mL}$ ), water content $\left(22 \%\right.$, v/v), $0.5 \mathrm{MPa} \mathrm{N}_{2}, 160^{\circ} \mathrm{C}, 3 \mathrm{~h}, 500$ rpm.

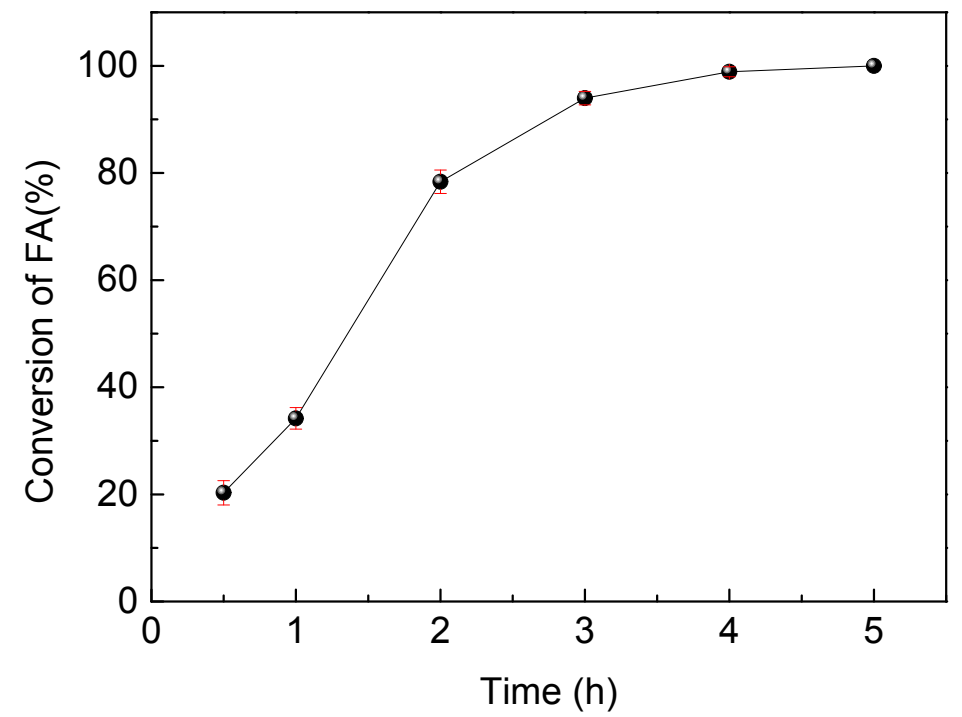

Fig. S7 FA decomposition over the Co-N-C catalyst. Reaction conditions: xylose $(0.2$ $\mathrm{mmol}$ ), Co-N-C (30 mg), FA/xylose=20 (mole ratio), solvent (water+1,4-dioxane, 3.5 $\mathrm{mL})$, water content $(22 \%, \mathrm{v} / \mathrm{v}), 0.5 \mathrm{MPa} \mathrm{N}_{2}, 160^{\circ} \mathrm{C}, 500 \mathrm{rpm}$.

Table S1 The reaction rate constants $(\mathrm{k})$ of one-pot xylose transformation under different temperature.

\begin{tabular}{ccc}
\hline $\mathrm{T} / \mathrm{K}$ & $\mathrm{k} / \mathrm{h}^{-1}$ & $\mathrm{R}^{2}$ \\
\hline 403 & 0.2978 & 0.9960 \\
413 & 0.5476 & 0.9869 \\
423 & 1.2714 & 0.9945 \\
\hline
\end{tabular}




\begin{tabular}{lll}
\hline 433 & 1.5896 & 0.9901 \\
443 & 4.9037 & 0.9743 \\
\hline
\end{tabular}

Reaction conditions: xylose $(0.2 \mathrm{mmol}), \mathrm{FA} / \mathrm{xylose}=20$ (mole ratio), solvent (water+1,4-dioxane, $3.5 \mathrm{~mL}$ ), water content (22\%, v/v), $0.5 \mathrm{MPa} \mathrm{N}_{2}, 500 \mathrm{rpm}$.

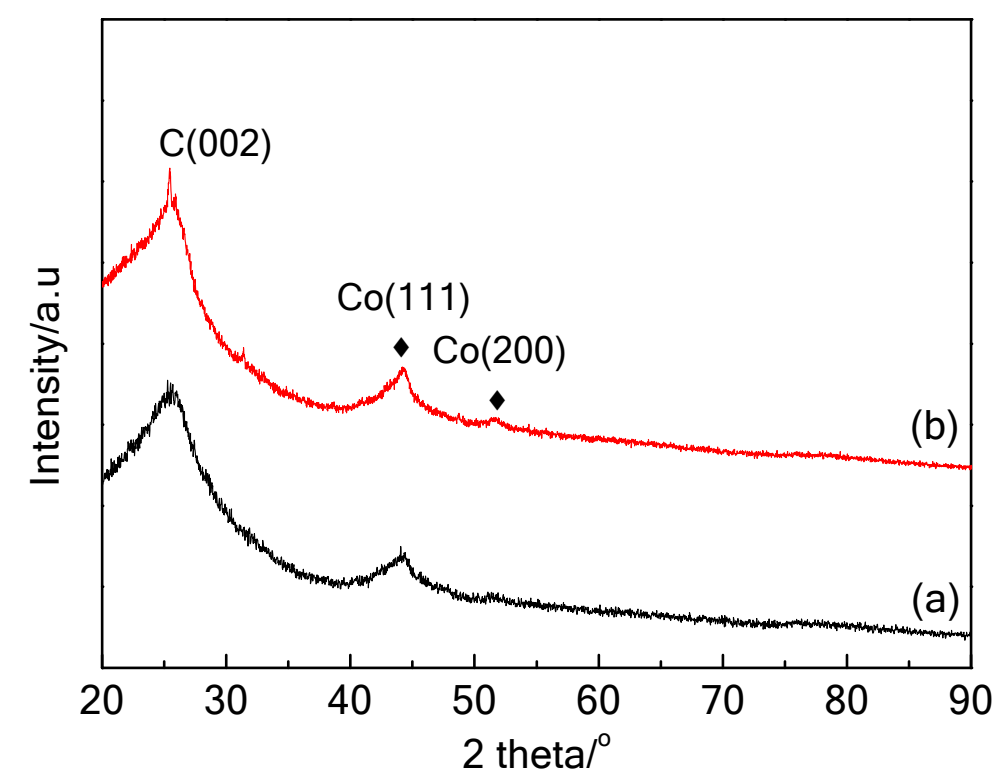

Fig. S8 XRD patterns of (a) fresh Co-N-C and (b) 5 times reused Co-N-C.
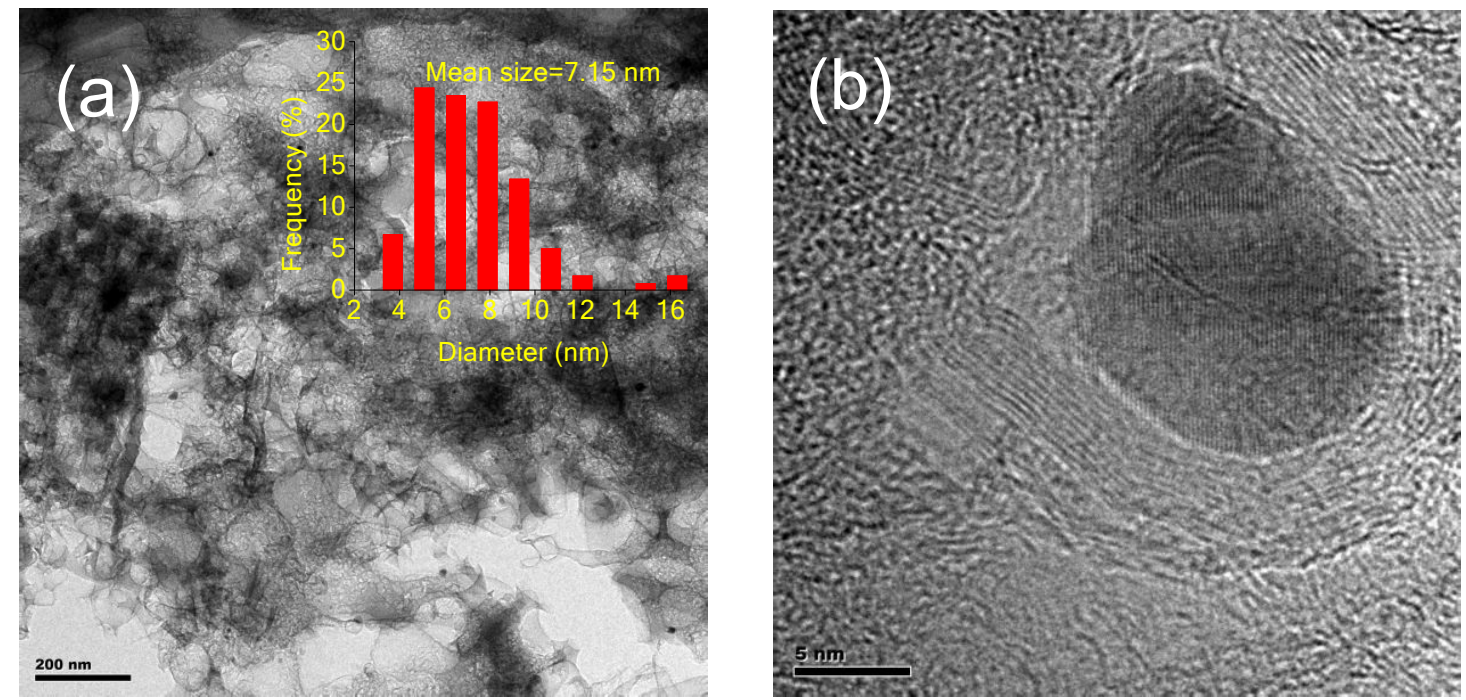

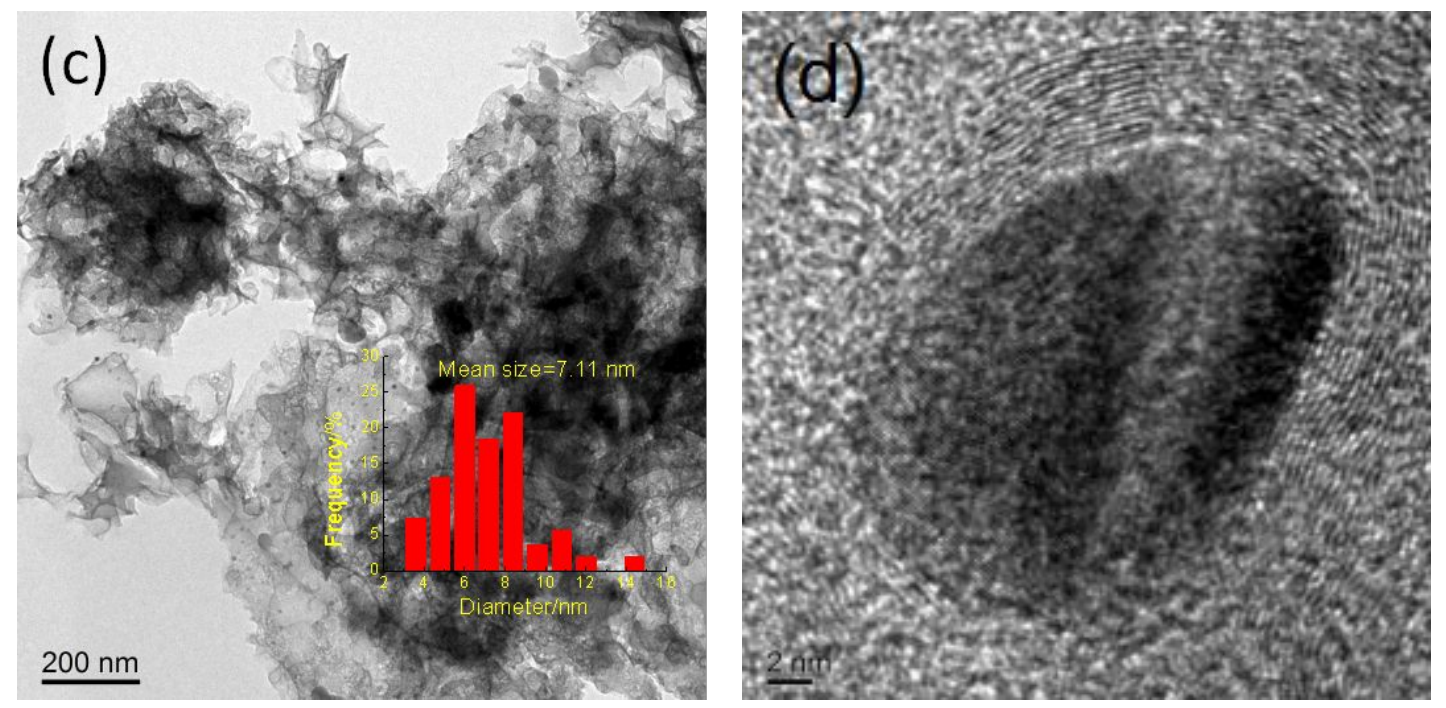

Fig. S9 TEM images of (a, b) fresh Co-N-C and (c, d) 5 times reused Co-N-C. The inserts in (a) and (c) are corresponding histograms of Co particle size distribution.
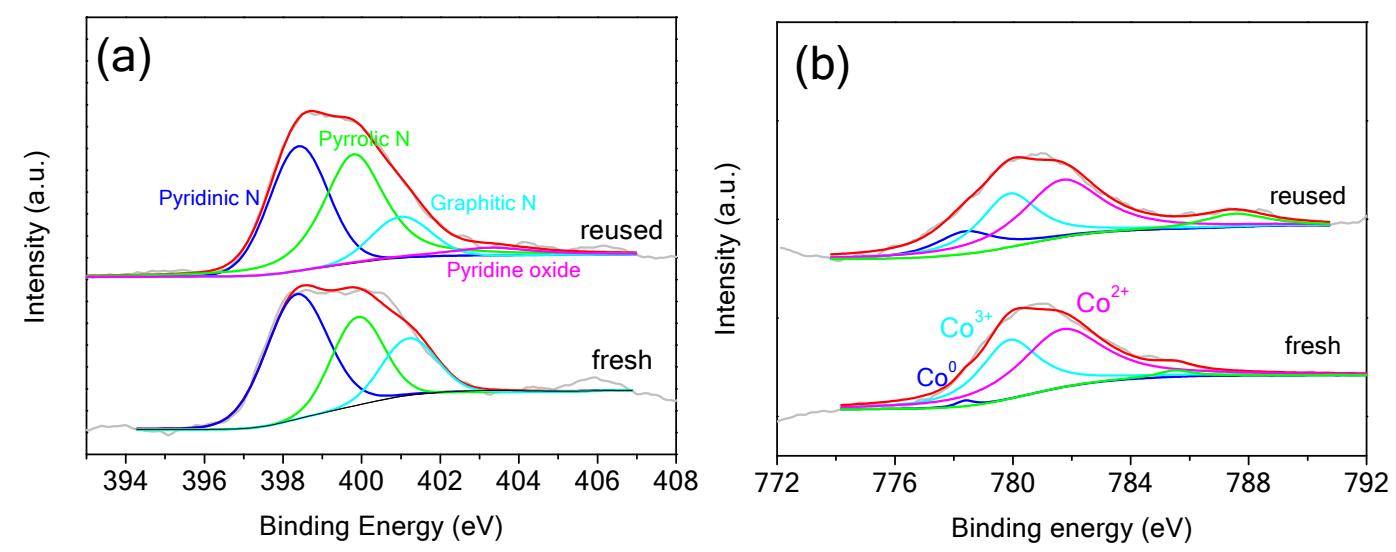

Fig. S10 (a) N1s and (b) Co2p spectra of fresh and reused Co-N-C catalysts. 
Table S2 Representative works for FOL production from sugars.

\begin{tabular}{|c|c|c|c|c|}
\hline catalysts & $\begin{array}{l}\text { hydrogen } \\
\text { donor }\end{array}$ & reaction conditions & yield $(\%)$ & ref. \\
\hline Homogeneous Ir catalyst & Formic acid & $\begin{array}{l}\text { 1: } 20 \mathrm{mmol} \mathrm{D} \text {-xylose, } 1 \mathrm{ml} \mathrm{DMSO}+10 \mathrm{ml} \mathrm{THF}, 2 \mathrm{~mol} \text { formic acid, } 150^{\circ} \mathrm{C}, 7 \mathrm{~h} \text {; } \\
\text { 2: } 2 \mathrm{mmol} \mathrm{Et}_{3} \mathrm{~N}+0.1 \mathrm{mmol} \mathrm{Ir}+20 \mathrm{mmol} \text { formic acid, } 40^{\circ} \mathrm{C}, 5 \mathrm{~min} \text {. }\end{array}$ & FOL yield $=63 \%$ & 1 \\
\hline $\mathrm{ZrO}_{2}-\mathrm{SO}_{4}+\mathrm{Pt} / \mathrm{SiO}_{2}$ & Isopropanol & $\mathrm{SO}_{4} / \mathrm{Pt}$ molar ratio $=8, \mathrm{H}_{2} \mathrm{O}$-Isopropanol $(1: 3), 130^{\circ} \mathrm{C}, 6 \mathrm{~h}$. & $\begin{array}{r}\text { xylose conv. }=65 \% \\
\text { FOL selec. }=51 \%\end{array}$ & 2 \\
\hline$\beta$ zeolite & Isopropanol & $\mathrm{H}_{2} \mathrm{O}$-Isopropanol (0.0026:1), 30 bar $\mathrm{N}_{2}, 130^{\circ} \mathrm{C}, 1 \mathrm{~h}$. & FOL yield $=75 \%$ & 3 \\
\hline 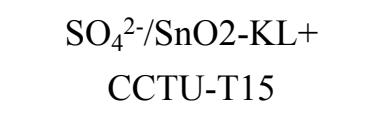 & biocatalysis & $\begin{array}{l}\text { 1: } \mathrm{SO}_{4}{ }^{2-} / \mathrm{SnO} 2-\mathrm{KL} \text {, toluene- } \mathrm{H}_{2} \mathrm{O}(1: 2), 170^{\circ} \mathrm{C}, 30 \mathrm{~min} \\
\text { 2: CCTU-T15, glucose, toluene- } \mathrm{H}_{2} \mathrm{O}(1: 3), 30^{\circ} \mathrm{C}, 6 \mathrm{~h} \text {. }\end{array}$ & FOL yield $=74.3 \%$ & 4 \\
\hline $\begin{array}{l}\mathrm{SO}_{4}{ }^{2-} / \mathrm{SnO}_{2}-\mathrm{MMT}+ \\
\mathrm{CCTU}-\mathrm{T} 14\end{array}$ & biocatalysis & $\begin{array}{l}\text { 1: } \mathrm{SO}_{4}^{2-/} \mathrm{SnO}_{2}-\mathrm{MMT}, \mathrm{pH} 6.5,170^{\circ} \mathrm{C}, 20 \mathrm{~min} \\
\text { 2: CCTU-T14, glucose, } \mathrm{pH} 6.5,30^{\circ} \mathrm{C}, 24 \mathrm{~h} \text {. }\end{array}$ & FOL yield $=41.9 \%$ & 5 \\
\hline $\mathrm{Pt} / \mathrm{ZrO}_{2}-\mathrm{SO}_{4}$ & $\mathrm{H}_{2}$ & Acid/metal ratio=142, $\mathrm{H}_{2} \mathrm{O}$-Isopropanol(1:1), $3 \mathrm{MPa} \mathrm{H}_{2}, 130^{\circ} \mathrm{C}$. & $\begin{array}{l}\text { xylose conv. }=32 \% \\
\text { FOL selec. }=27 \%\end{array}$ & 6 \\
\hline $\begin{array}{l}\text { Amberlyst-15+ } \\
\qquad \mathrm{Ru} / \mathrm{C}\end{array}$ & $\mathrm{H}_{2}$ & $\begin{array}{c}\mathrm{Ru} / \mathrm{C}(0.4 \mathrm{~g}), \text { Amberlyst-15 }(10 \mathrm{~g}), \text { xylose }(10 \mathrm{~g}), 2.5 \mathrm{MPa} \mathrm{H}_{2}, \mathrm{H}_{2} \mathrm{O}(300 \mathrm{~mL}) \\
\text { cyclohexane }(300 \mathrm{~mL}), 135^{\circ} \mathrm{C} .\end{array}$ & $\begin{array}{c}\text { xylose conv. }=32 \% \\
\text { tetrahydrofurfuryl alcohol } \\
\text { selec. }=50 \%\end{array}$ & 7 \\
\hline $\begin{array}{l}\mathrm{Pt} / \mathrm{SBA}-15- \\
\mathrm{SO}_{3} \mathrm{H}\end{array}$ & $\mathrm{H}_{2}$ & $\mathrm{H}_{2} \mathrm{O}$-Isopropanol (1:1), 30 bar $\mathrm{H}_{2}, 130^{\circ} \mathrm{C}, 6 \mathrm{~h}$. & $\begin{array}{l}\text { xylose conv. }=65 \% \\
\text { FOL selec. }=83 \%\end{array}$ & 8 \\
\hline $\mathrm{H} \beta+\mathrm{Cu} / \mathrm{ZnO} / \mathrm{Al}_{2} \mathrm{O}_{3}$ & $\mathrm{H}_{2}$ & $\begin{array}{c}\gamma \text { - butyrolactone- } \mathrm{H}_{2} \mathrm{O}, \text { WHSV }=0.023 \mathrm{~h}^{-1}, \mathrm{H}_{2} \text { feed }=25 \mathrm{mLmin}^{-1}, 0.1 \mathrm{MPa} \mathrm{H}_{2}, \\
150^{\circ} \mathrm{C} .\end{array}$ & FOL yield $=87.2 \%$ & 9 \\
\hline
\end{tabular}




\section{References}

(1) Thananatthanachon, T.; Rauchfuss, T. B. Efficient route to hydroxymethylfurans from sugars via transfer hydrogenation. ChemSusChem 2010, 3, 1139-1141.

(2) Perez, R. F.; Fraga, M. A. Hemicellulose-derived chemicals: one-step production of furfuryl alcohol from xylose. Green Chem. 2014, 16, 3942-3950.

(3) Paulino, P. N.; Perez, R. F.; Figueiredo, N. G.; Fraga, M. A. Tandem dehydration-transfer hydrogenation reactions of xylose to furfuryl alcohol over zeolite catalysts. Green Chem. 2017, 19, 3759-3763.

(4) He, Y.-C.; Jiang, C.-X.; Chong, G.-G.; Di, J.-H.; Wu, Y.-F.; Wang, B.-Q.; Xue, X.-X.; Ma, C.-L. Chemical-enzymatic conversion of corncob-derived xylose to furfuralcohol by the tandem catalysis with $\mathrm{SO}_{4}{ }^{2-} / \mathrm{SnO}_{2}$-kaoline and E. coli CCZU-T15 cells in toluene-water media. Bioresour. Technol. 2017, 245, 841-849.

(5) He, Y.-C.; Jiang, C.-X.; Jiang, J.-W.; Di, J.-H.; Liu, F.; Ding, Y.; Qing, Q.; Ma, C.-L. One-pot chemo-enzymatic synthesis of furfuralcohol from xylose. Bioresour. Technol. 2017, 238, 698-705.

(6) Perez, R. F.; Canhaci, S. J.; Borges, L. E.; Fraga, M. A. One-step conversion of xylose to furfuryl alcohol on sulfated zirconia-supported Pt catalyst-Balance between acid and metal sites. Catal. Today 2017, 289, 273-279.

(7) Ordomsky, V. V.; Schouten, J.; Van der Schaaf, J.; Nijhuis, T. Biphasic single-reactor process for dehydration of xylose and hydrogenation of produced furfural. Appl. Catal., A 2013, 451, 6-13.

(8) Canhaci, S. J.; Perez, R. F.; Borges, L. E.; Fraga, M. A. Direct conversion of xylose to furfuryl alcohol on single organic-inorganic hybrid mesoporous silica-supported catalysts. Appl. Catal., B 2017, 207, 279-285.

(9) Cui, J.; Tan, J.; Cui, X.; Zhu, Y.; Deng, T.; Ding, G.; Li, Y. Conversion of xylose to furfuryl alcohol and 2-methylfuran in a continuous fixed-bed reactor. ChemSusChem 2016, 9, 1259-1262. 